\title{
Perbandingan Hasil Deteksi Plagiarisme Dokumen dengan Metode Jaro- Winkler Distance dan Metode Latent Semantic Analysis
}

\author{
Tinaliah $\left.^{*}, 1\right)$ Triana Elizabeth ${ }^{2)}$ \\ ${ }^{1)}$ Program Studi Manajemen Informatika, AMIK MDP \\ Jl. Rajawali No 14, Palembang, Indonesia 30113 \\ ${ }^{2)}$ Program Studi Sistem Informasi, STMIK Global Informatika MDP \\ Jl. Rajawali No 14, Palembang, Indonesia 30113
}

Cara sitasi: T. Tinaliah, and T. Elizabeth, "Perbandingan Hasil Deteksi Plagiarisme Dokumen dengan Metode Jaro-Winkler Distance dan Metode Latent Semantic Analysis," Jurnal Teknologi dan Sistem Komputer, vol. 6, no. 1, Jan. 2018. doi: 10.14710/jtsiskom.6.1.2018.7-12, [Online].

\begin{abstract}
Various methods are applied in the application of plagiarism detection to help check the similarity of a document. Jaro-Winkler Distance can measure the distance between two strings. However, this method basically depends on the position of the word. Latent Semantic Analysis emphasizes the words contained in the document regardless of its linguistic character. This study compares the results of plagiarism detection using the Jaro-Winkler Distance and the Latent Semantic Analysis method. From comparing results of Jaro-Winkler Distance method and Latent Semantic Analysis method, Jaro-Winkler Distance method is better than Latent Semantic Analysis method if using the same test data. JaroWinkler Distance method will give plagiarism result 100\% and Latent Semantic Analysis method will give plagiarism result $97,14 \%$.

Keywords - plagiarism; undergraduate thesis; JaroWinkler Distance; Latent Semantic Analysis
\end{abstract}

Abstrak - Beragam metode diterapkan dalam aplikasi deteksi plagiarisme untuk membantu mengecek tingkat kesamaan sebuah dokumen. Metode JaroWinkler Distance dapat mengukur kesamaan antara dua buah string dan sangat bergantung pada urutan atau posisi kata. Latent Semantic Analysis mementingkan kata-kata yang terkandung di dalam dokumen tanpa memperhatikan karakter linguistiknya. Penelitian ini melakukan perbandingan hasil deteksi plagiarisme dengan menggunakan metode Jaro-Winkler Distance dan metode Latent Semantic Analysis. Hasil pendeteksian plagiarisme dokumen menggunakan metode Jaro-Winkler Distance memberikan hasil yang lebih baik daripada metode Latent Semantic Analysis, yaitu jika data yang dibandingkan sama persis maka akan menghasilkan nilai plagiat sebesar 100\%, sedangkan metode Latent Semantic Analysis menghasilkan nilai plagiat sebesar 97,14\%.

Kata Kunci - plagiarisme; karya akhir; Jaro-Winkler Distance; Latent Semantic Analysis

*) Penulis korespondensi (Tinaliah)

Email: tinaliah@mdp.ac.id

\section{Pendahuluan}

Informasi merupakan sesuatu hal yang sangat penting saat ini, dimana perkembangan teknologi yang semakin pesat menyebabkan informasi semakin terus bertambah. Banyak cara yang dapat dilakukan untuk dapat memperoleh informasi, misalnya melalui buku, majalah, Internet dan sumber-sumber informasi lainnya. Informasi yang diperoleh diharapkan merupakan informasi yang terbaru dan dapat dipercaya. Namun, beberapa orang memanfaatkan informasi berupa karya orang lain untuk diakui sebagai karya ciptaannya sendiri atau melakukan plagiarisme. Plagiarisme dapat dikelompokkan berdasarkan proporsi atau persentase kata, kalimat, atau paragraf yang dibajak, yaitu plagiarisme ringan $(<30 \%)$, plagiarisme sedang (30 $70 \%$ ) dan plagiarisme besar atau total $(>70 \%)$ [1].

Umumnya praktik plagiarisme terjadi akibat para penulis termasuk mahasiswa terbiasa untuk mengambil bahan tulisan tanpa mencantumkan sumber bahan tersebut berasal. Selain itu, ada juga yang telah mencantumkan sumbernya namun menyalin sama persis dengan sumber, sehingga masih terindikasi sebagai sebuah plagiat. Zulkarnain [2] menyatakan bahwa cara untuk menghindari plagiarisme adalah senantiasa taat pada gaya selingkung, melakukan pengutipan (menyitir) secara langsung, dan melakukan parafrasa terhadap kutipan yang dirujuk.

Contoh praktik nyata plagiarisme di kampus terjadi saat pembuatan skripsi / tesis / disertasi. Mahasiswa yang sedang membuat laporan skripsi, tesis atau disertasi sering mengacu pada bahan-bahan skripsi/tesis/disertasi yang telah dibuat oleh kakakkakak kelasnya terdahulu. Mahasiswa terbiasa untuk mengambil landasan teori yang ada pada bab 2, sehingga apabila ditelusuri, sebagian besar isi dari landasan teori mereka sama persis. Untuk menghindari plagiarisme yang semakin banyak terjadi, maka diperlukan sebuah aplikasi yang dapat mengecek seberapa besar tingkat plagiarisme sebuah dokumen, agar dapat mengurangi tingkat plagiarisme terutama pada saat pembuatan skripsi / tesis / disertasi.

Metode yang dapat melakukan pendeteksian tingkat plagiarisme sebuah dokumen ada berbagai macam, salah 


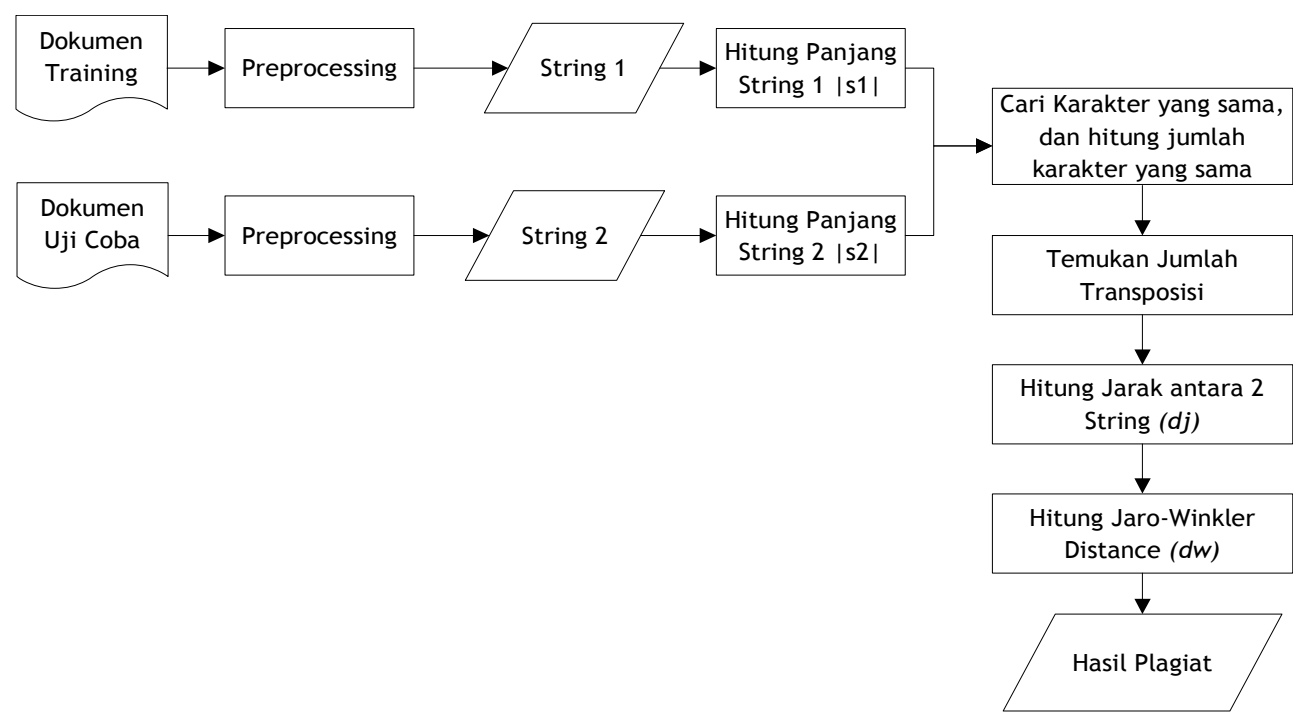

Gambar 1. Proses dalam algoritme Jaro-Winkler Distance [3]

satunya adalah metode Jaro-Winkler Distance. JaroWinkler Distance memiliki kelebihan yaitu dapat mengukur kesamaan antara dua string dimana metode ini biasanya digunakan di dalam pendeteksian duplikat dokumen. Semakin tinggi nilai Jaro-Winkler Distance untuk dua buah string, maka semakin mirip string tersebut. Nilai normalnya adalah 0 yang menandakan tidak adanya kesamaan dan 1 yang menandakan adanya kesamaan. Metode ini cocok untuk pendeteksian plagiarisme, namun sangat bergantung pada urutan ataupun posisi kata. Metode ini telah digunakan dalam aplikasi di [3]-[5]. Kornain dkk. [3], Kurniawati dkk. [4] dan Faranika dkk. [5] mengembangkan aplikasi pengukur kemiripan dokumen berbahasa Indonesia menggunakan metode Jaro-Winkler Distance.

Metode yang lain adalah Latent Semantic Analysis (LSA). Metode ini digunakan pada himpunan dokumen yang banyak dan terstruktur untuk mengekstraksi dan mewakili penggunaan arti kata dengan perhitungan statistik dan aljabar linier. LSA merupakan metode yang mementingkan kata-kata yang terkandung di dalam dokumen tanpa memperhatikan karakter linguistiknya. LSA mampu mendeteksi adanya kemiripan makna kata yang diberikan, walaupun kata tersebut muncul atau tidak muncul pada korpus. LSA merupakan suatu metode pembuatan representasi istilah (term) berbasis vektor yang dianggap mampu menangkap inti sari dari suatu dokumen maupun kalimat. Metode ini telah digunakan dalam aplikasi di [6]-[8] untuk mengukur kemiripan dokumen berbahasa Indonesia menggunakan metode LSA. Perkasa dkk. [6] menggunakannya untuk sistem ujian online essay, sedangkan Wicaksono dkk. [7], dan Khairunnisa dkk. [8] untuk deteksi kemiripan dokumen akademik. Tudesman dkk. [9] menggunakan metode Vector Space Model (VSM) untuk mendeteksi kemiripan dokumen akademik.

Perbandingan metode deteksi telah dilakukan untuk mengetahui performansi dari metode dalam menganalisis tingkat kesamaan sebuah dokumen, seperti yang dilakukan oleh [10]-[12]. Soleman dan Purwarianti
[10] membandingkan antara metode VSM dan LSA. Tinaliah [11] membandingkan deteksi otomatis menggunakan metode LSA dan centroid-based summarization. Leonardo dan Hansun [12] melakukan deteksi otomatis menggunakan metode Rabin-Karp dan Jaro-Winkler Distance berdasarkan efektivitas dan kecepatan prosesnya. Penelitian ini bertujuan menganalisis hasil deteksi tingkat plagiarisme dengan menggunakan metode Jaro-Winkler Distance dan metode Latent Semantic Analysis untuk menganalisis tingkat kesamaan sebuah dokumen jurnal skripsi mahasiswa dengan dokumen lainnya. Analisis dilakukan terhadap deteksi kesamaan yang melalui proses stemming dan tanpa proses stemming.

\section{Metode Penelitian}

Data yang digunakan pada penelitian ini terbagi menjadi 2, yaitu :

1. Data latih berjumlah 100 buah dokumen yang digunakan untuk proses pelatihan data pada metode LSA.

2. Data uji coba berjumlah 5 buah dokumen, yaitu :

a. Abstrak yang diambil sama persis pada salah satu dokumen korpus.

b. Abstrak yang telah dilakukan perubahan isi.

c. Abstrak yang berisi paragraf pertama saja pada salah satu dokumen korpus.

d. Abstrak yang digabungkan dengan isi abstrak lain pada dokumen data latih.

e. Abstrak yang berbeda dengan dokumen pada korpus.

Data tersebut merupakan data seperti yang digunakan oleh Kornain dkk. [3] dan Tudesman dkk. [9] yang melakukan pengukuran kemiripan dokumen tersebut berurutan dengan menggunakan metode JaroWinkler Distance dan VSM. Data tersebut adalah berupa dokumen abstrak dari jurnal skripsi Program Teknik Informatika STMIK Global Informatika MDP. Jurnal yang diambil dikonversi ke format .txt. Jurnal 


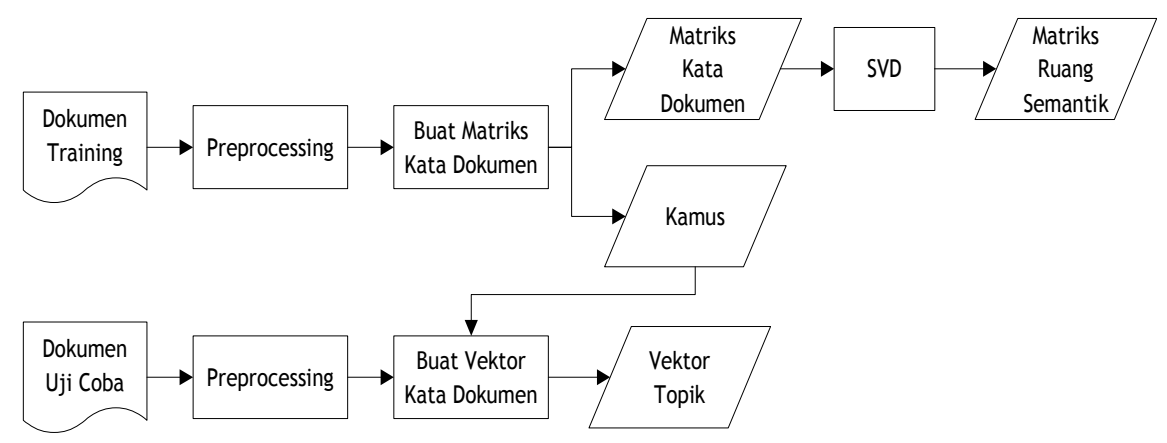

Gambar 2. Proses dalam metode LSA

Skripsi diambil dari situs jurnal skripsi mahasiswa/i MDP, yaitu http://eprints.mdp.ac.id/.

Dalam tahap persiapan dokumen, yang dilakukan adalah meliputi tahap case folding, tokenisasi, pembuangan stopwords, dan stemming. Proses dari metode Jaro-Winkler Distance ditunjukkan dalam Gambar 1. Metode ini terdiri dari 3 tahap, yaitu menghitung panjang string, menemukan jumlah karakter yang sama di dalam dua buah string dan menemukan jumlah transposisi [13]. Penghitungan jarak antara dua string $\left(d_{j}\right)$, yaitu $s_{1}$ dan $s_{2}$ dilakukan dengan menggunakan Persamaan 1. Jarak teoretis dua buah karakter yang sama dapat dibenarkan jika tidak melebihi $\left(\frac{\max \left(\left|s_{1}\right|,\left|s_{2}\right|\right)}{2}\right)-1$

$$
d_{j}=\frac{1}{3} \times\left(\frac{m}{\left|S_{1}\right|}+\frac{m}{\left|S_{2}\right|}+\frac{m-t}{m}\right)
$$

dimana :

$$
\begin{array}{ll}
m & =\text { jumlah karakter yang sama persis } \\
\left|s_{1}\right| & =\text { panjang string } 1 \\
\left|s_{2}\right| & =\text { panjang string } 2 \\
t & =\text { jumlah transposisi }
\end{array}
$$

Jarak Jaro-Winkler $\left(d_{w}\right)$ menggunakan skala prefiks $(p)$ yang menyediakan sebuah prefiks dalam sebuah himpunan string. Jarak $d_{w}$ dinyatakan dalam Persamaan 2. Panjang prefiks ( $l$ ) menyatakan panjang awalan, yaitu panjang karakter yang sama dengan string yang dibandingkan sampai ditemukannya ketidaksamaan (maksimal 4). Jarak Jaro untuk string $\mathrm{s}_{1}$ dan $\mathrm{s}_{2}$ dinyatakan sebagai $d_{j}$. Konstanta faktor skala $(p)$ mempunyai nilai standar menurut Winkler sebesar $p=0.1$.

$$
d_{w}=d_{j}+\left(\operatorname{lp}\left(1-d_{w}\right)\right)
$$

Proses pada metode LSA terdiri dari dua tahapan, yaitu tahap pelatihan data dan tahap pendeteksian plagiat. Proses pada metode LSA ditunjukkan pada Gambar 2. Proses metode LSA adalah data latih akan dibuat menjadi matriks kata dokumen, sehingga menghasilkan matriks kata dokumen dan kamus. Matriks kata dokumen akan dilakukan reduksi dimensinya oleh Singular Value Decompotion (SVD), sehingga menghasilkan matriks ruang semantik, yang di dalamnya berisi vektor-vektor kata. Data dari dokumen uji coba akan dibuat menjadi vektor kata dokumen
Tabel 1. Term yang dijumpai dalam $D_{1}$ dan $D_{2}$

\begin{tabular}{llcc}
\hline & \multicolumn{1}{c}{ Kata } & $\mathrm{D}_{1}$ & $\mathrm{D}_{2}$ \\
\hline $\mathrm{k}_{1}$ & Komputer & 1 & 1 \\
$\mathrm{k}_{2}$ & Kalang & 1 & 1 \\
$\mathrm{k}_{3}$ & Bidang & 1 & 0 \\
$\mathrm{k}_{4}$ & Didik & 1 & 0 \\
$\mathrm{k}_{5}$ & Institusi & 1 & 0
\end{tabular}

sehingga menghasilkan matriks topik sesuai dengan kamus dari data latih. Matriks topik berisi vektor topik yang mewakili topik inti dokumen. Tahap pelatihan dan tahap pendeteksian plagiat dilakukan dengan menggunakan tools TMG 5.0R6 yang didapat dari situs online TMG, yaitu http://scgroup20.ceid.upatras.gr:8000/tmg/.

Penilaian yang ada pada metode LSA adalah melakukan perhitungan cosine similarity antara matriks ruang semantik dengan vektor topik, sehingga menghasilkan nilai plagiat [14]. Cosine similarity digunakan untuk mengukur kedekatan antara dua buah vektor. Persamaan cosine similarity ditunjukkan dalam Persamaan 3.

$$
\operatorname{sim}\left(d_{j}, q\right)=\frac{d_{j} \cdot q}{\left|d_{j}\right||q|}
$$

dimana :

$$
\begin{aligned}
& d_{j}=\text { dokumen } j \\
& q=\text { dokumen query }
\end{aligned}
$$

\section{Hasil dan Pembahasan}

Cuplikan dokumen yang digunakan sebagai data latih dan data uji coba dalam penelitian ini ditunjukkan dalam Gambar 3 sampai Gambar 8. Secara keseluruhan, dokumen data latih adalah sejumlah 100 buah, sedangkan dokumen uji coba untuk menganalisis kinerja metode Jaro-Winkler Distance dan LSA adalah sejumlah 5 buah. Dokumen uji coba ini juga digunakan dalam Kornain dkk. [3] dan dalam Tudesman dkk. [9].

Proses perhitungan pada metode Jaro-Winkler Distance dan metode LSA untuk membandingkan kesamaan dua dokumen diuraikan dalam bab ini. Misalnya dokumen $\mathrm{D}_{1}$ dan $\mathrm{D}_{2}$ berisi string berikut:

$\mathrm{D}_{1}$ : Komputer digunakan banyak kalangan di berbagai bidang pendidikan dan institusi.

$\mathrm{D}_{2}$ : Komputer digunakan banyak kalangan untuk bekerja. 


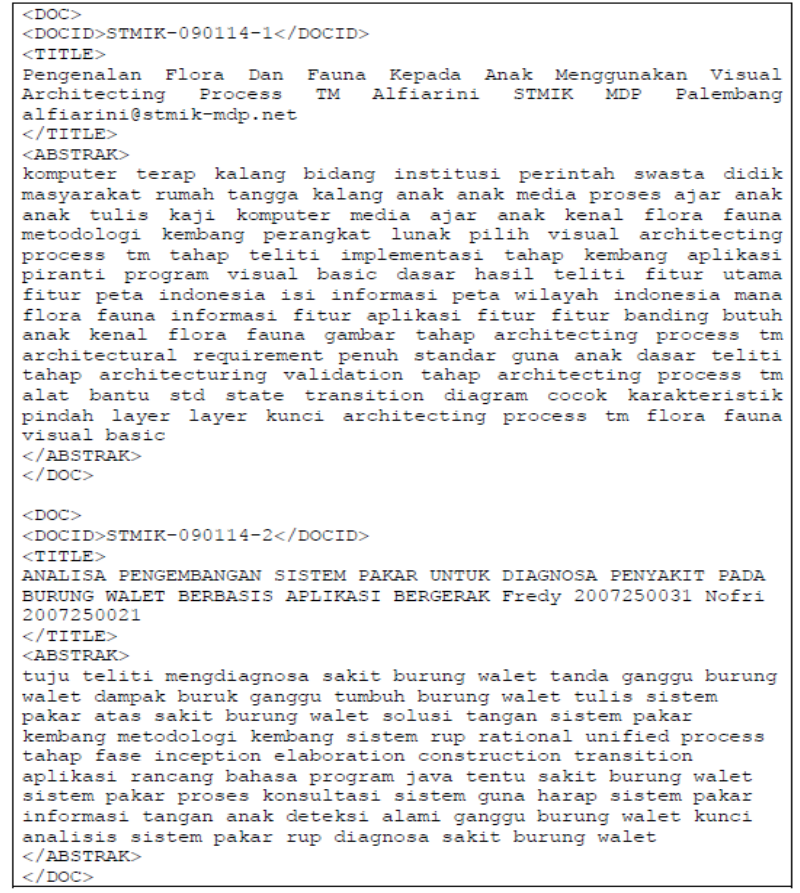

Gambar 3. Dokumen data latih

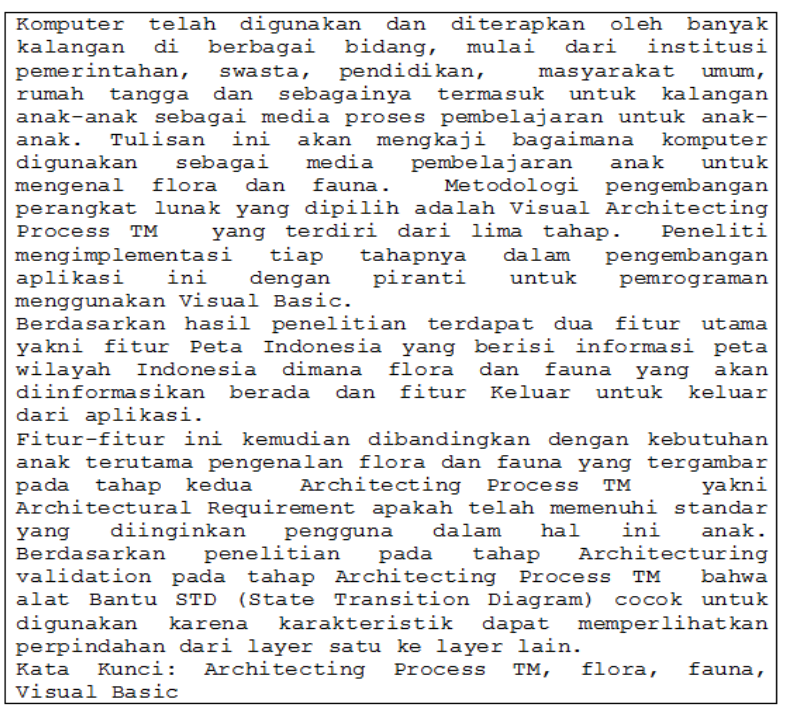

Gambar 4. Dokumen uji coba 1

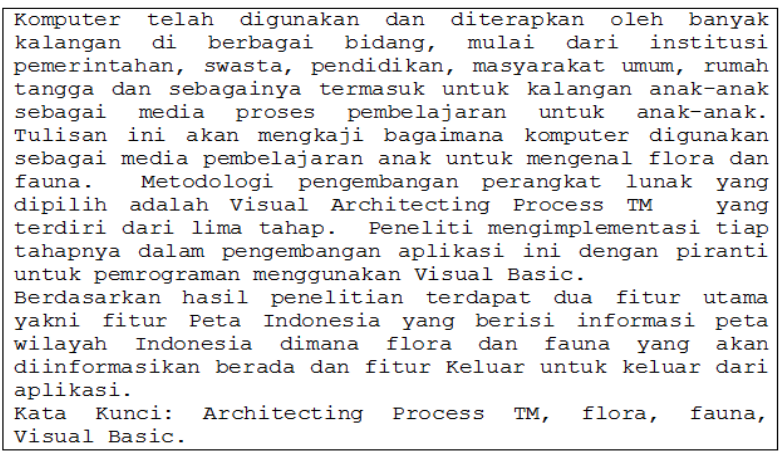

Gambar 5. Dokumen uji coba 2

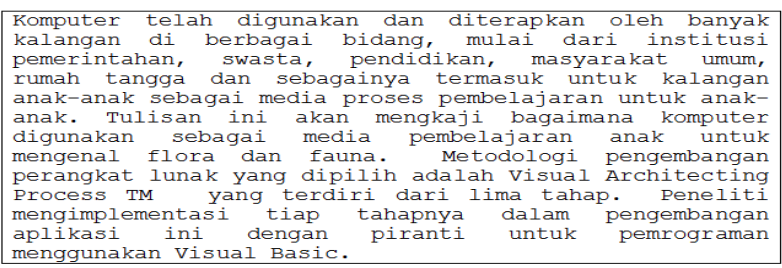

Gambar 6. Dokumen uji coba 3

Komputer telah digunakan dan diterapkan oleh banyak
kalangan di berbagai bidang, mulai dari institusi
pemerintahan, swasta, pendidikan, masyarakat umum,
rumah tangga dan sebagainya termasuk untuk kalangan
anak-anak sebagai media proses pembelajaran untuk anak-
anak. Chatting merupakan salah satu cara komunikasi
yang dilakukan dua orang atau lebih.
Pada aplikasi chatting berbasis teks antar ponsel ini,
penulis memanfaatkan teknologi bluetooth yang merupakan
media koneks wireless yang tersedia pada ponsel
sebagai media pengiriman data. Metode yang digunakan
dalam penelitian ini adalah metode korelasi sederhana
dengan menggunakan bantuan program aplikasi Spss
(Statistical product and Service Solutions). Aplikasi
ini dibangun dengan memperincikan berbagai aspek
keamanan data yang tersimpan di dalamny sehingga
pengguna aplikasi ini harus didaftarkan terlebih dahulu
oleh administrator agar tidak sembarang orang yang bisa
menggunakan aplikasi ini.
Kata kunci : Analisis, sistem pakar, Rup, diagnosa
penyakit pada burung walet

\section{Gambar 7. Dokumen uji coba 4}

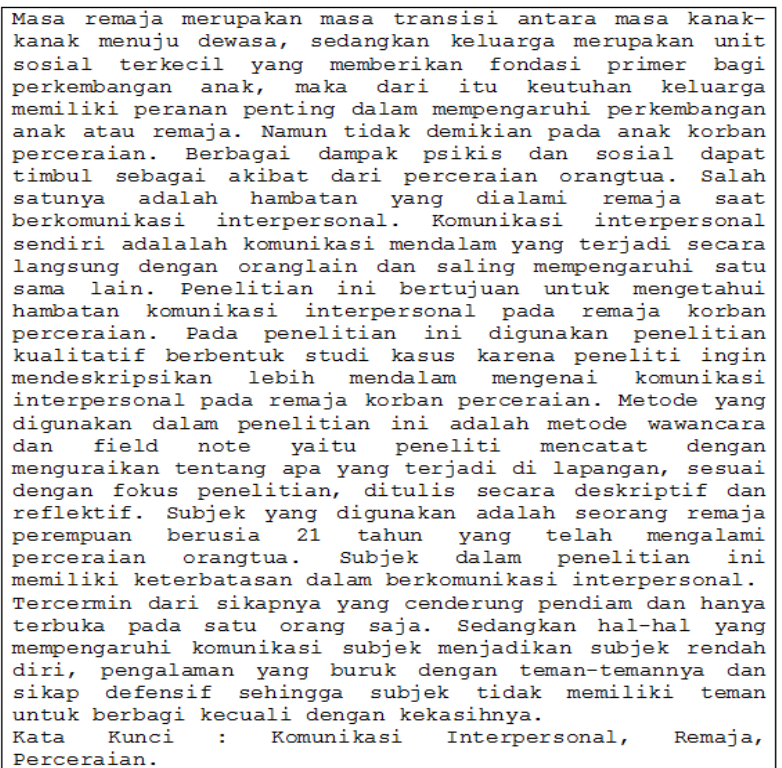

Gambar 8. Dokumen uji coba 5

Dokumen pada $\mathrm{D}_{1}$ dan $\mathrm{D}_{2}$ akan dilakukan preprocessing melalui tahapan case folding, tokenisasi, proses stemming dan pembuangan stopword. Hasil preprocessing-nya adalah sebagai berikut:

\section{$\mathrm{D}_{1}$ : komputer kalang bidang didik institusi. \\ $\mathrm{D}_{2}$ : komputer kalang}

Dalam perhitungan pada metode Jaro-Winkler Distance, dokumen $\mathrm{D}_{1}$ dianggap sebagai $s_{1}$, dan dokumen $\mathrm{D}_{2}$ dianggap sebagai $s_{2}$. Untuk kasus dalam dokumen D1 dan D2 tersebut di atas, maka nilai parameternya adalah sebagai berikut:

$$
\begin{aligned}
& m=2 \\
& \left|s_{1}\right|=5
\end{aligned}
$$


Tabel 2. Hasil pengujian melalui proses stemming

\begin{tabular}{ccc}
\hline Pengujian & $\begin{array}{c}\text { Jaro-Winkler } \\
\text { Distance }\end{array}$ & LSA \\
\hline Uji Coba 1 & $100 \%$ & $97,14 \%$ \\
Uji Coba 2 & $92,29 \%$ & $93,32 \%$ \\
Uji Coba 3 & $88,32 \%$ & $86,91 \%$ \\
Uji Coba 4 & $69,28 \%$ & $26,43 \%$ \\
Uji Coba 5 & $28,95 \%$ & $26 \%$ \\
\hline
\end{tabular}

Tabel 3. Hasil pengujian tanpa melalui proses stemming

\begin{tabular}{ccc}
\hline Pengujian & $\begin{array}{c}\text { Jaro-Winkler } \\
\text { Distance }\end{array}$ & LSA \\
\hline Uji Coba 6 & $100 \%$ & $97,53 \%$ \\
Uji Coba 7 & $92,29 \%$ & $94,64 \%$ \\
Uji Coba 8 & $88,32 \%$ & $87,16 \%$ \\
Uji Coba 9 & $70,04 \%$ & $35,64 \%$ \\
Uji Coba 10 & $32.5 \%$ & $33,22 \%$ \\
\hline
\end{tabular}

$$
\begin{aligned}
& \left|s_{2}\right|=2 \\
& \mathrm{t}=0
\end{aligned}
$$

Nilai jarak Jaro-nya, $d_{j}$, dengan menggunakan Persamaan 1 adalah:

$$
d_{j}=\frac{1}{3} \times\left(\frac{2}{5}+\frac{2}{2}+\frac{2-0}{2}\right)=0,792
$$

Jika diperhatikan susunan $s_{1}$ dan $s_{2}$ dapat diketahui nilai $1=2$, dan nilai konstan $\mathrm{p}=0,1$. Nilai jarak JaroWinkler, $d_{w}$, dengan menggunakan Persamaan 2 adalah:

$$
d_{w}=0,792+(2 \times 0.1(1-0,792))=0,833
$$

Jadi, dokumen $\mathrm{D}_{1}$ dan $\mathrm{D}_{2}$ mempunyai kemiripan sebesar 0,833 atau $83,3 \%$.

Hasil perhitungan pada metode LSA menggunakan cosine similarity dinyatakan dalam Tabel 1 . Vektor $\mathrm{D}_{1}$ bernilai $1 \mathrm{k}_{1}+1 \mathrm{k}_{2}+1 \mathrm{k}_{3}+1 \mathrm{k}_{4}+1 \mathrm{k}_{5}$, sedangkan vektor $\mathrm{D}_{2}$ bernilai $1 \mathrm{k}_{1}+1 \mathrm{k}_{2}+0 \mathrm{k}_{3}+0 \mathrm{k}_{4}+0 \mathrm{k}_{5}$. Perhitungan cosine similarity menggunakan Persamaan 3 adalah sebagai berikut:

$$
\begin{aligned}
\operatorname{sim}\left(D_{1}, D_{2}\right) & =\frac{(1 \times 1)+(1 \times 1)+(1 \times 0)+(1 \times 0)+(1 \times 0)}{\sqrt{1^{2}+1^{2}+1^{2}+1^{2}+1^{2}} \times \sqrt{1^{2}+1^{2}+0^{2}+0^{2}+0^{2}}} \\
& =0,632
\end{aligned}
$$

Jadi, dokumen $\mathrm{D}_{1}$ dan $\mathrm{D}_{2}$ mempunyai kemiripan sebesar 0,632 atau $63,2 \%$.

Pengujian yang dilakukan pada penelitian ini adalah membandingkan kelima dokumen uji coba dengan dokumen pertama data latih menggunakan metode Jaro-Winkler Distance dan metode LSA. Pengujian akan dilakukan sebanyak 10 kali, dengan menggunakan 5 data uji coba yang akan dibandingkan dengan dokumen yang isinya sama persis dengan data uji coba pertama. Proses pengujian akan menilai hasil deteksi plagiarisme melalui proses stemming dan tanpa melalui proses stemming.

Hasil pengujian yang telah dilakukan ditunjukkan pada Tabel 2 dan Tabel 3. Metode Jaro-Winkler
Distance, dengan algoritme sesuai [13], dapat digunakan untuk mendeteksi kemiripan teks berbahasa Indonesia dan memberikan hasil plagiat sebesar $100 \%$, jika menggunakan data uji coba yang sama dengan data yang dilatih. Secara keseluruhan, metode Jaro-Winkler Distance dengan stemming mempunyai nilai deteksi yang lebih baik daripada tanpa stemming, seperti yang telah dihasilkan dalam [3]. Dalam penelitian ini tidak dilakukan pengukuran waktu yang dibutuhkan untuk melakukan deteksi seperti halnya dalam [5], yang menyatakan bahwa lamanya waktu pengecekan ditentukan oleh ukuran, tipe dan kandungan isi dokumen. Penambahan tahap stemming yang memberikan kinerja lebih baik dalam deteksi dapat diberikan ke aplikasi deteksi plagiarisme berbasis web dalam [4].

Metode LSA dalam [14] juga telah dapat mendeteksi kemiripan antar dokumen teks berbahasa Indonesia, seperti halnya dalam [6]-[8]. Wicaksono dkk. [7] telah menambahkan model Bayesian untuk menjaga urutan term / kata sehingga hasil deteksi kemiripan yang dihasilkan dapat lebih baik. Seperti halnya dalam Tudesman dkk. [9] yang menggunakan VSM, penelitian ini juga menganalisis pengaruh pemberian tahap stemming dalam proses deteksi menggunakan LSA dimana proses stemming dapat memberikan hasil deteksi yang lebih baik.

Dari hasil dari pengujian kedua metode tersebut dapat dinyatakan bahwa pada hasil pengujian metode Jaro-Winkler Distance menghasilkan hasil deteksi plagiarisme yang lebih baik daripada metode LSA. Jika dibandingkan dengan [10] yang menyatakan LSA lebih baik daripada VSM, maka dapat dinyatakan juga bahwa Jaro-Winkler Distance ini memberikan hasil deteksi kemiripan yang lebih baik daripada VSM. Namun, apabila dokumen telah dimodifikasi, metode LSA memberikan hasil deteksi yang lebih baik sebesar 93,32\% pada uji coba 2. Metode LSA ini dapat memberikan hasil deteksi yang lebih baik jika digabungkan dengan centroid-based summarization [11].

Penelitian ini telah menghasilkan analisis perbandingan metode Jaro-Winkler Distance dan LSA yang menggunakan proses stemming dan tanpa stemming untuk mendeteksi kemiripan. Perbandingan metode dinyatakan berdasarkan kemampuan dalam deteksi kemiripan. Penelitian lebih lanjut dapat dilakukan untuk membandingkan efektivitas dan kecepatan proses kedua metode seperti yang dilakukan oleh Leonardo dan Hansun [12].

\section{KESIMPULAN}

Berdasarkan hasil pengujian pada penelitian ini dapat disimpulkan bahwa hasil Jaro-Winkler Distance memberikan hasil yang lebih baik daripada metode Latent Semantic Analysis, yaitu jika data yang dibandingkan sama persis maka akan menghasilkan nilai plagiat sebesar $100 \%$, sedangkan metode Latent Semantic Analysis menghasilkan nilai plagiat sebesar 97,14\%. Hasil pendeteksian plagiarisme dokumen 
menggunakan metode Latent Semantic Analysis memberikan hasil yang baik apabila dokumen telah dimodifikasi.

\section{DAfTAR PUSTAKa}

[1] S. Sastroasmoro, "Beberapa Catatan tentang Plagiarisme," Majalah Kedokteran Indonesia, vol. 56, no. 1, pp. 1-6, 2006.

[2] Z. Zulkarnain, "Plagiarisme Dalam Menghasilkan Karya Tulis Ilmiah," April 2013. [Online]. Available: http://www.unja.ac.id/2013/04/10/profdr-ir-h-zulkarnain-mhortsc/. [Diakses: Nov, 15, 2017]

[3] A. Kornain, F. Yansen, and T. Tinaliah, "Penerapan Algoritma Jaro-Winkler Distance Untuk Sistem Deteksi Plagiarisme pada Dokumen Teks Berbahasa Indonesia," Skripsi, STMIK MDP, Oktober 2014.

[4] A. Kurniawati, S. Puspitodjati, and S. Rahman, "Implementasi Algoritma Jaro-Winkler Distance untuk Membandingkan Kesamaan Dokumen Berbahasa Indonesia", Skripsi Program Studi Sistem Informasi, Universitas Gunadarma, 2010.

[5] Y. Faranika, H. Kurniawan, and N. Nikentari, "Sistem Pengukur Kemiripan Dokumen Menggunakan Algoritma Jaro-Winkler Distance," Skripsi, Universitas Maritim Raja Ali Haji, 2014.

[6] D. A. Perkasa, E. Saputra, and M. Fronita, "Sistem Ujian Online Essay dengan Penilaian Menggunakan Metode Latent Semantic Analysis (LSA), “ Jurnal Rekayasa dan Manajemen Sistem Informasi, vol. 1, no. 1, Februari 2015, pp. 1-9.

[7] D. W. Wicaksono, M. I. Irawan, and A. M. Rukmi, "Sistem Deteksi Kemiripan Antar Dokumen Teks Menggunakan Model Bayesian pada Term Latent
Semantic Analysis (LSA)," Jurnal Sains dan Seni POMITS, vol. 3, no. 2, 2014, pp.41-46.

[8] N. Khairunnisa, D. S. Sihabudin, and A. Wibowo, "Aplikasi Pendeteksi Plagiat dengan Menggunakan Metode Latent Semantic Analysis (Studi Kasus : Laporan TA PCR),“ Jurnal Aksara Komputer Terapan, vol. 1, no. 2, 2012.

[9] T. Tudesman, E. Oktalina, T. Tinaliah, Y. Yoannita, "Sistem Deteksi Plagiarisme Dokumen Bahasa Indonesia Menggunakan Metode Vector Space Model," Skripsi, STMIK MDP, Oktober 2014.

[10] S. Soleman, and A. Purwirianti, "Experiments on the Indonesian Plagiarism Detection using Latent Semantic Analysis," in 2014 2nd International Conference on Information and Communication Technology (IcoICT), 28-30 May 2014, Bandung, Indonesia.

[11] T. Tinaliah, "Ringkasan Multi-Dokumen Berbahasa Indonesia Secara Otomatis Menggunakan Metode Latent Semantic Analysis dan Centroid-Based Summarization," Tesis, Universitas Indonesia, 2013.

[12] B. Leonardo, and S. Hansun, "Text Documents Plagiarism Detection using Rabin-Karp and JaroWinkler Distance Algorithms," Indonesian Journal of Electrical Engineering and Computer Science, vol. 5, no. 2, pp. 462-471, 2017.

[13] W. E. Winkler, "String Comparator Metrics and Enhanced Decision Rules in the Fellegi-Sunter Model of Record Linkage," in Proceedings of the Section on Survey Methods, American Statistical Association, 1990, pp. 354-359.

[14] S. T. Dumais, "Latent Semantic Analysis," Annual Review of Information Science and Technology, vol. 38, no. 1, pp. 188-230, 2004. 